УДК 343.98 .067

DOI 10.18101/2658-4409-2019-4-58-65

\title{
К ВОПРОСУ О НЕОБХОДИМОСТИ СОЗДАНИЯ МЕТОДИК ПОДДЕРЖАНИЯ ГОСУДАРСТВЕННОГО ОБВИНЕНИЯ
}

\section{(C) Гармаев Юрий Петрович}

доктор юридических наук, профессор, Бурятский государственный университет имени Доржи Банзарова Россия, 670000, г. Улан-Удэ, ул. Сухэ-Батора, 6

E-mail: garmaeff@yandex.ru

\section{(C) Попова Елена Ильинична}

кандидат юридических наук, доцент, Восточно-Сибирский государственный университет технологий и управления Россия, 670013, г. Улан-Удэ, ул. Ключевская, 40В

E-mail: popovaelena03@yandex.ru

Авторы анализируют научную дискуссию по вопросу расширения предмета науки криминалистики. На основе изучения различных точек зрения, высказываемых на протяжении длительного периода времени, анализа правоприменительной практики резюмируется, что создание частных криминалистических методик поддержания государственного обвинения является востребованным и актуальным.

Ключевые слова: криминалистика; государственный обвинитель; прокурор; криминалистическая методика; криминалистические рекомендации; суд; судебное разбирательство.

\section{Для цитирования}

Гармаев Ю. П., Попова Е. И. К вопросу о необходимости создания методик поддержания государственного обвинения // Вестник Бурятского государственного университета. Юриспруденция. 2019. Вып. 4. С. 58-65.

Как и любая наука, имеющая существенное значение для развития той или иной сферы жизнедеятельности общества, криминалистика, традиционно нацеленная на создание научных продуктов для следователей, в последнее время значительно расширила предмет своего исследования [2, c. $29 ; 19$, с. $87 ; 30$, с. 93-101]. Сегодня практически не вызывает возражений необходимость создания систем криминалистических рекомендаций, 
Ю. П. Гармаев, Е. И. Попова. К вопросу о необходимости создания методик поддержания государственного обвинения

адресованных работникам прокуратуры и судьям, высказываются предложения о криминалистическом обеспечении деятельности представителей адвокатского сообщества [1, с. 97-100; 13, с. 98-115], участников цивилистического процесса [7, с. 12-14; 12, с. 316; 21, с. 216] и др.

Заметим, что если необходимость создания методик судебного разбирательства ставится под сомнение, то целесообразность разработки соответствующих научных продуктов, адресованных государственным обвинителям, практически не оспаривается. Так, например, имеет место следующее мнение: «Известно, что суд в процессе разбирательства уголовных дел, особенно в сложных случаях, применяет планирование судебного следствия, конструирование и проверку судебных версий, анализ показаний при допросах и т. д. Но требует ли это разработки особых приемов и средств, идущих от специальных наук, или же достаточно точного соблюдения процессуального порядка рассмотрения уголовных дел и обобщения практики применения соответствующих норм закона? Нет, не требует» $[29$, с. 95]. После высказанного практически безапелляционного утверждения, автор продолжает: «В публикуемых работах по вопросам науки уголовного процесса подробно анализируются нормы уголовнопроцессуального закона, регламентирующие судебное следствие, обобщается практика их применения и на основе этого разрабатываются соответствующие рекомендации. Кроме того, не исключается, что судьи могут использовать эпизодически (на практике так и делается) тактические приемы, разработанные криминалистикой для предварительного расследования» [4, с. 19-20]. Высказанное А. Н. Васильевым свыше сорока лет назад мнение поддерживается и в настоящее время [29, с. 95].

Обозначенная точка зрения близка и О. Я. Баеву, который также высказался в том смысле, что нет необходимости включать в число субъектов судебного исследования преступлений криминалистическими средствами суд. В обоснование своей позиции он привел следующие тезисы:

1. Задача суда - единственного органа осуществления правосудия по уголовным делам - слушать, исследовать и принимать законное, обоснованное и справедливое решение. Суд по определению решает задачи не поискового, а чисто исследовательского характера.

2. Не суд как таковой, а две состязающиеся в суде стороны (обвинения и защиты) являются субъектами криминалистики при судебном рассмотрении уголовных дел: прокурор - государственный обвинитель и адвокат - защитник подсудимого. Не суд, а они, осуществляя свои процессуальные функции, используют криминалистические средства для собира- 
ния, представления, исследования доказательств и убеждения суда в правомерности и обоснованности избранной позиции $[1$, с. 97,99$]$.

На целесообразность создания систем тактико- и методикокриминалистических рекомендаций, необходимых для эффективного поддержания государственного обвинения и разрешения уголовного дела судом по существу, справедливо обращается внимание на протяжении достаточно длительного периода времени. В свое время еще С. П. Митричев писал: «Криминалистическая наука обслуживает предварительное и судебное следствие, разрабатывая научные приемы и методы раскрытия преступлений и методы исследования вещественных доказательств» [23, c. 21]. В 2003 г., спустя непродолжительное время после вступления в законную силу УПК РФ, Н. П. Кириллова отмечала: «...назрела необходимость разработки научных рекомендаций в области применения норм уголовно-процессуального права, криминалистической тактики и методики, которые позволят с должной эффективностью осуществлять деятельность по поддержанию обвинения в суде» $[15$, с. 6]. Сходную позицию занимает и ряд других авторов, в числе которых и С. Л. Кисленко. По его мнению, «продолжают превалировать подходы классической “следственной” криминалистики, что объективно порождает трудности в практической области реализации ее рекомендаций прокурором в суде. При этом разрешить сложившиеся противоречия путем простого эмпирического объяснения отдельных новых фактов представляется непродуктивным, поскольку не позволяет решить проблему на принципиальном уровне» [16, с. 11].

Как видим, многие исследователи весьма аргументированно доказывают актуальность создания систем научно обоснованных криминалистических рекомендаций для государственных обвинителей. И уже сейчас известно достаточно большое число работ, посвященных тактике и методике поддержания государственного обвинения $[6$, с. $266 ; 9$, с. $33 ; 10$, c. $218 ; 11$, c. $234 ; 17$, c. $287 ; 20$, c. $418 ; 24$, c. $110-113 ; 25$, c. $256 ; 26$, c. $121-$ $128 ; 27$, c.; 28, c. 770$]$.

Представляется верным высказанное утверждение о том, что «досудебное и судебное производство - это единое и неделимое поле деятельности для науки криминалистики. Нельзя разрабатывать криминалистическую технику, тактику и методику для предварительного следствия без учета ситуаций судебного следствия, как и криминалистическую технику, тактику и методику судебного следствия без учета ситуаций предварительного следствия и деятельности участников уголовного судопроизводства» $[8$, с. 289$]$. 
Ю. П. Гармаев, Е. И. Попова. К вопросу о необходимости создания методик поддержания государственного обвинения

Стоит отметить, что криминалисты все чаще и чаще в своих исследованиях не только уделяют внимание проблемам формирования методик расследования либо поддержания государственного обвинителя или судебного разбирательства, но и предпринимают, на наш взгляд, весьма успешные попытки их объединения в рамках единых методик [5, с. 204]. В обоснование необходимости создания криминалистических методик на основе такого подхода указывается, что «криминалистическая методика расследования преступлений и методика поддержания государственного обвинения в суде имеют много общих черт. Нельзя не увидеть наличия в их структуре ряда общих организационных и криминалистических компонентов» [14, с. 250]. Вместе с тем вынуждены согласиться с О. Н. Коршуновой, которая констатирует, что «несмотря на то, что на протяжении многих десятилетий разработка методических рекомендаций по раскрытию и расследованию преступлений ведется весьма успешно, существующие в настоящее время рекомендации, призванные обеспечить эффективность уголовного преследования такими субъектами, как государственные обвинители, фрагментарны и не могут рассматриваться как достаточные для обеспечения целей уголовного преследования» [20, с. 4].

А между тем сами работники прокуратуры отмечают недостаток рекомендаций криминалистического характера, которые были бы адресованы именно им (78\% из числа опрошенных). Поясняя свое мнение, респонденты указывают (далее приводим ответы не дословно, а в обобщенном виде), что знание только лишь норм уголовного и уголовнопроцессуального законодательства не гарантирует успех при поддержании государственного обвинения и уже тем более не обеспечивает их знаниями по прогнозированию разрешения судебных ситуаций. Соответствующие знания, при отсутствии системы научно обоснованных криминалистических рекомендаций, появляются зачастую только с опытом ${ }^{1}$.

Итак, одним из промежуточных и, как представляется, достаточно аргументированным является вывод о необходимости создания систем криминалистических рекомендаций для прокуроров, поддерживающих государственное обвинение. При этом отметим, что криминалистическое обеспечение деятельности [3, с. 64; 18, с. 62] названных субъектов требует, как представляется, приложения усилий наверное даже не одного, а нескольких научных коллективов [28, с. 770]. И хотя названное направле-

1 Нами приводятся данные интервьюирования 33 работников прокуратуры Республики Бурятия, Иркутской и Новосибирской области. 
ние активно разрабатывается рядом ученых-криминалистов, тем не менее, как представляется, находится только в самом начале своего становления.

\section{Литература}

1. Баев О. Я. О предмете современной криминалистики // Современная криминалистика: проблемы, тенденции, имена (к 90-летию профессора Р. С. Белкина): материалы 53 криминалистических чтений: в 3 ч. М.: Академия управления МВД России, 2012. Ч. 1. С. 97-100.

2. Белкин Р. С. Криминалистика, проблемы сегодняшнего дня. Злободневные вопросы российской криминалистики. М., 2001. С. 29.

3. Белкин Р. С. Криминалистическое обеспечение деятельности криминальной милиции и органов предварительного расследования / под ред. Т. В. Аверьяновой, Р. С. Белкина. М., 1997. С. 64.

4. Васильев А. Н. Следственная тактика. М., 1976. С. 19-20.

5. Вдовин А. Н. Особенности методики расследования и поддержания государственного обвинения по уголовным делам о преступлениях, связанных с незаконным оборотом оружия и боеприпасов (по материалам приграничных регионов Сибирского федерального округа): автореф. дис. ... канд. юр. наук. Краснодар, 2015. С. 204.

6. Волнянская Л. Т. Криминалистические аспекты поддержания государственного обвинения по делам о преступлениях несовершеннолетних: дис. ... канд. юр. наук. СПб., 2007. С. 266.

7. Волчецкая Т. С. Прикладные задачи современной криминалистической науки // Закон и правопорядок в третьем тысячелетии. III Балтийский юридический форум: материалы междунар. науч.-практ. конф. СПб., 2015. C. 12-14.

8. Гавло В. К., Ким Д. В. Тактика и методика судебного следствия есть сфера приложения научного потенциала криминалистики // Актуальные вопросы криминалистического обеспечения уголовного судопроизводства: материалы Всерос. науч.-практ. конф. (24 ноября 2009 г.). Иркутск: Изд-во БГУЭП, 2010. С. 289.

9. Ганичева Е. А. Особенности поддержания государственного обвинения по делам о кражах, грабежах, разбоях: автореф. дис. ... канд. юр. наук. М., 2011. С. 33.

10. Гармаев Ю. П. Основы методики расследования и поддержания государственного обвинения по делам о взяточничестве. Улан-Удэ: Издво Бурят. гос. ун-та, 2006. С. 218.

11. Гармаев Ю. П., Шашин Д. Г. Особенности криминалистической методики расследования и поддержания государственного обвинения по 
Ю. П. Гармаев, Е. И. Попова. К вопросу о необходимости создания методик поддержания государственного обвинения

уголовным делам о незаконном сбыте наркотиков. М.: Юрлитинформ, 2009. $234 \mathrm{c}$.

12. Жижина М. В. Теория и практика применения современной криминалистики в цивилистическом процессе: дис. ... д-ра юр. наук. М., 2016. C. 316.

13. Зашляпин Л. А. Основные компоненты теории адвокатского мастерства в уголовном судопроизводстве. Екатеринбург: Изд-во Урал. унта, 2007. C. $98-115$.

14. Исаенко В. Н. Понятие методики государственного обвинения / Криминалистика для государственных обвинителей: учебник / под ред. А. Ф. Козусева, В. Н. Исаенко, А. М. Кустова. М.: Норма: ИНФРА-М, 2015. С. 250.

15. Кириллова Н. П. Поддержание государственного обвинения в суде. СПб., 2003. С. 6.

16. Кисленко С. Л. Концептуальные основы криминалистической методики поддержания государственного обвинения в уголовном судопроизводстве: монография. М.: Юрлитинформ, 2018. С. 11.

17. Кисленко И. Л., Кисленко С. Л. Криминалистическое основы поддержания государственного обвинения: монография. М.: Юрлитинформ, 2013. C. 287.

18. Коломацкий В. Г. Криминалистическое обеспечение деятельности органов внутренних дел по расследованию преступлений // Криминалистика. М.: Изд-во Академии МВД РФ, 1995. Т. 1. С. 62.

19. Комиссаров В. И. Тактика защиты и предмет криминалистики: взгляд со стороны // Профессиональная деятельность адвоката как объект криминалистического исследования. Екатеринбург, 2002. С. 87.

20. Коршунова О.Н. Уголовно-процессуальные и криминалистические проблемы уголовного преследования: дис. ... д-ра юр. наук. М., 2006. С. 418.

21. Ладошкин А. С. Особенности криминалистической методики расследования преступлений, связанных с фальсификацией доказательств в гражданском и арбитражном судопроизводстве: дис. ... канд. юр. наук. Новосибирск, 2019. С. 216.

22. Латыпова К. С. Особенности методики расследования и поддержания государственного обвинения по уголовным делам о нарушениях правил дорожного движения и эксплуатации транспортных средств, связанных с наездами на пешеходов: дис. ... канд. юр. наук. Улан-Удэ, 2017. C. 212.

23. Митричев С. П. Теоретические основы советской криминалистики. М., 1965. С. 21. 
24. Попова Е. И., Вдовин А. Н. Особенности подготовки государственного обвинителя к судебному разбирательству по уголовным делам о незаконным обороте оружия и боеприпасов, назначенных к разбирательству судом в особом порядке (гл. 40 УПК РФ) // Алтайский юридический вестник. 2016. № 2(14). С. 256.

25. Попова Е. И., Вдовин А. Н. Расследование и поддержание обвинения по делам о незаконном обороте оружия: монография / науч. ред. Ю. П. Гармаев. М.: Юрлитинформ, 2019. С. 256.

26. Попова Е. И., Латыпова К. С. Типичные судебные ситуации по уголовным делам о нарушении правил дорожного движения и безопасности транспортных средств, связанных с наездами на пешеходов и рекомендации государственному обвинителю по их разрешению // Алтайский юридический вестник. 2019. № 1(25). С. 121-128.

27. Рохлин В. И., Дворянский А. М. Организация и методика участия прокурора в рассмотрении судами уголовных дел: метод. рекомендации. СПб., 1994. С. 56.

28. Руководство для государственного обвинителя: учеб. пособие / под ред. О. Н. Коршуновой. 2-е изд., испр. и доп. СПб., 2011. С. 770.

29. Шмонин А. В. Методология криминалистической методики: монография. М.: Юрлитинформ, 2010. С. 95.

30. Яблоков Н. П., Головин А. Ю. Криминалистика: природа и система. М.: Юристъ, 2005. С. 93-101. 
Ю. П. Гармаев, Е. И. Попова. К вопросу о необходимости создания методик поддержания государственного обвинения

ON THE QUESTION OF THE NEED TO CREATE A METHODOLOGY FOR MAINTAINING PUBLIC PROSECUTION

Yury P. Garmaev

Doctor of Law, Professor

Buryat state University named after Dorji Banzarov

6 Sukhe-Batora St., Ulan-Ude 670000, Russia

E-mail: garmaeff@yandex.ru

Elena I. Popova

Candidate of Legal Sciences, associate Professor

East Siberia State University of Technology and Management

Building №4, 40V Klyuchevskata St., Ulan-Ude 670013, Russia

E-mail: popovaelena03@yandex.ru

The authors analyze the scientific discussion on the expansion of the subject of science of criminology. Based on the study of various points of view expressed over a long period of time, the analysis of law enforcement practice, it is summarized that the creation of private forensic techniques to support public prosecution is in demand and relevant.

Keywords: criminalistics; public Prosecutor; Prosecutor; forensic methodology; forensic recommendations; court, trial. 